\title{
Doğuştan ağır nötropenide fenotip-genotip ilişkisi
}

\section{The phenotype-genotype relationship in severe congenital neutropenia patients}

\author{
Safa Barış1,2, Elif Karakoç Aydiner, Ayça KIykım, Havva Hasret Çağan, Kaan Boztug*, Işıl Barlan \\ T.C. Sağıı Bakanlı̆̆ı, Marmara Üniversitesi Eğitim ve Araştırma Hastanesi, Çocuk Allerji ve Immmünoloji Bilim Dalı, İstanbul, Türkiye \\ * Research center for Molecular Medicine of the Austrian Academy of Sciences (CeMM), Department of Pediatrics and Adolescent Medicine, \\ Medical University of Vienna, Viyana, Avusturya
}

\section{Özet}

Amaç: Doğuştan ağır nötropeni, yaşamın erken döneminde sepsis, apse, omfalit, diş eti iltihabı gibi enfeksiyon bulgularıyla karşımıza çıkan nadir görülen kalıtsal bir hastalıktır. Çalışmamızda genetik tanısı konulan hastalarımızın mutasyonları ile klinik bulguları arasındaki ilişkiyi değerlendirdik. Gereç ve Yöntem: Kliniğimizde takip edilen toplam altı hastanın klinik, laboratuvar ve tedavi verileri elde edilerek hem hastalara, hem de diğer aile bireylerine (ebeveynler ve çocuklar) mutasyon analizi yapıldı.

Bulgular: Doğuştan ağır nötropeni nedeniyle izlenen altı olgunun erken dönemde en sık apse, otit ve diş eti iltihabı nedeniyle başvurduğu gözlendi. Dört olguda $H A X-1$, iki olguda G6PC3 mutasyonu saptandı. Glükoz-6-fosfataz katalitik alt birim 3 mutasyonu olan olgularda yüzeyel deri venlerinde belirginleşme, meme başı çöküklüğü, üçgen yüz görünümü vardı. HS1-ilişkili protein X-1 mutasyonu saptanan olgularda gelişme geriliği, konuşamama, konvulziyon ve öğrenme güçlüğü gözlendi.

Çıkarımlar: Tekrarlayıcı, ağır enfeksiyon öyküsü olan olgularda öncelikle nötrofil sayısına dikkat edilmesi, değişik klinik bulgularla başvuranlarda erken tanı ve tedavi açısından gen analizinin yanı sıra genetik danışmanın yapılması önemlidir. (Türk Ped Arş 2012; 47: 272-7) Anahtar sözcükler: Doğuştan ağır nötropeni, G6PC3, HAX1, Kostmann hastalığı

\section{Summary}

Aim: Severe congenital neutropenia is a rare hereditary disease presenting with infections such as sepsis, abscess, omphalitis and gingivitis in early life. We evaluated the association between clinical findings and mutations in our patients with severe congenital neutropenia.

Material and Method: The clinical and laboratory findings of six patients with severe congenital neutropenia were obtained and the diagnosis was confirmed by mutation analysis in all family members (parents and children).

Results: The most common clinical presentation included formation of abscess and presence of otitis and gingivitis. The mutation analysis by DNA sequencing revealed HAX-1 mutation in four and G6PC3 mutation in two patients. Prominent superficial veins, inverted nipple and triangular face were observed in patients with G6PC3 mutation. In addition, developmental delay, convulsion, inability to speak and learning difficulties were observed in two patients with HAX1 mutation.

Conclusions: In patients with severe, recurrent infections, assessment of neutrophil count and consideration of various presentations of severe congenital neutropenia are critical for establishing early diagnosis and for successful treatment of the disease. Additionally, genetic counseling and mutation analysis should be offered to these patients. (Turk Arch Ped 2012; 47: 272-7)

Key words: G6PC3, HAX1, Kostmann disease, severe congenital neutropenia

\section{Giriş}

Doğuştan ağır nötropeni (DAN), nadir görülen kalıtımsal bir immün yetersizlik hastalığıdır. Nadir görülen bir hastalık olup sıklığı yaklaşık milyonda 1-2'dir (1). İlk defa 1956 yılında Rolf Kostman (2) tarafından İsveçli bir ailede tanımlanmış olup yaşamın erken döneminde ağır nötropeni, tekrarlayan deri enfeksiyonları, diş eti iltihabı, periodontit, otit, pnömoni ve sepsis ile karşımıza çıkabilmekte ve kemik iliğinde nötrofil gelişiminde promiyelosit/miyelosit evresinde duraksama ile belirgin bir hastalıktır (3).

Doğuştan ağır nötropenide birden fazla gen tek başına benzer klinik fenotipten sorumlu olabilmektedir (lokus heterojenitesi). Bu durumda hastalık, otozomal baskın 
(dominant) (OB), çekinik (resesif) (OÇ), X'e bağlı veya sporadik geçişler gösterebilmekte ve akraba evliliğinin sık olduğu ülkemizde daha fazla görülmesi beklenmektedir $(4,5)$. Moleküler düzeyde DAN'a neden olabilecek genler sıklık sırasına göre ELA-2 (nötrofil elastaz, sporadik veya OB), HAX-1 (HS1-ilişkili protein X-1, OR) ve G6PC3 (Glükoz-6-fosfataz katalitik alt birim 3, OÇ)'dir. Daha nadir görülenler ise, Wiskott-Aldrich sendromu (WAS), X'e bağlı) ve GFI-1 ("Growth factor independent-1", OB)'dir. Tablo 1'de DAN tipleri ve kalıtım şekilleri gösterilmiştir.

Tedavide nötrofil yapımını artırmak amacıyla koloni uyarıcı faktör (G-CSF) kullanılmakta ve olguların çoğu tedaviye yanıt vermektedir (1). Tedavisiz bırakılanlar erken dönemde ciddi bakteriyel enfeksiyonlar nedeniyle kaybedilmektedir. Bu olgularda \%30 oranında miyelodisplastik sendrom veya akut miyeloid lösemi gelişme riski bulunmaktadır.

Çalışmamızda genetik tanısı konulan hastalarımızın mutasyonları ile klinik bulguları arasındaki ilişkiyi değerlendirdik.

\section{Gereç ve Yöntem}

Çalışmamıza 2007-2011 yılları arasında kliniğimizde izlenen beş aile alındı. Tüm olgular DAN olarak izlenmekte olup tanı, erken dönemde başlayan ağır bakteriyel enfeksiyonlar ve periferik kanda mutlak nötrofil sayısının 500/mm 3 altında olmasıyla konuldu. Olguların demografik özellikleri, akrabalık durumu, tanı yaşı, izlem süresi, klinik ve laboratuvar bulguları (lökosit sayısı, serum immünglobülin değerleri, lenfosit alt grupları) ve tedavi seçenekleri kaydedildi.

Olguların ailelerinden imzalanmış aydınlatılmış onam formu alındıktan sonra mutasyon analizi için alınan $5 \mathrm{ml}$ heparinli kandan DNA'lar elde kit kullanılarak izole edildi (Promega, Madison, WI, USA). Daha sonra ELA-2, HAX-1, G6PC3 bölgeleri için özgün "primer"lar kullanılarak PCR cihazı ile ilgili bölgelerin ekzon kısımları çoğaltıldı. Elde edilen ürünler jel elektroforezde yürütülerek kontrol edildi. Deoksiribonükleik asit dizileme cihazı (Hitachi Applied Biosystems 3130x1 Genetic Analyser, CA, USA) kullanılarak ilgili bölgelerin nükleotid dizilimi elde edilerek esas genin nükleotid dizilimi ile karşılaştırıldı. ELA2, HAX-1, G6PC3 için sırasıyla NM_001972,2, NM_006118,3, NM_138387,3 esas gen olarak kabul edildi. Mutasyon analizleri S.B. tarafından CeMM (Center for Molecular Medicine of the Austrian Academy of Sciences)-Viyana/Avusturya'da gerçekleştirildi.

\section{Bulgular}

\section{Klinik bulgular}

Çalışmaya alınan altı olgunun tanı yaşı 45,5 ay (aralık: $1-120$ ay), yakınmaların başlangıç yaşı 5,83 ay (aralık: $1-12$ ay), tanıda gecikme süresi 38,3 ay (aralık: 1-108 ay), ortalama takip izlem 21,3 ay (aralık: 10-37 ay) idi. Demografik, klinik ve laboratuvar bulguları Tablo 2'de sunulmuştur.

Tüm olgularda akraba evliliği ve büyüme-gelişme geriliği gözlendi. Olgu bir ve iki aynı aileden kardeş hastalardı. Tanı öncesi ağır bakteriyel enfeksiyonlar tüm olgularda görülürken, tüm olgularda "perfore" otit ve karaciğer-dalak büyüklüğü saptandı. Dört olguda HAX-1 mutasyonu, iki olguda G6PC3 mutasyonu saptandı. Farklı genotiplerle ilişkili fenotipik özellikler aşağıdaki gibidir:

- HAX-1 mutasyonu saptanan olguların ikisinde nörolojik tutulum olarak olgu üçte ağır zeka geriliği, konuşamama ve konvulziyon (Şekil 1), olgu 4'de ise öğrenme güçlügü ve okul başarısında düşüklük gözlendi.

- G6PC3 mutasyonu olan iki olguda yüzeyel deri venlerinde belirginleşme (Şekil 1), meme başı çöküklüğü (olgu 6), üçgen yüz görünümü (olgu 6), öğrenme güçlüğü (olgu 5 ve 6) vardı. Her iki olguda G6PC3 mutasyonu ile ilişkili ürogenital anomali yoktu.

\section{Laboratuvar ve radyolojik bulgular}

Tanı öncesi ortalama nötrofil sayısı 210/mm³ (aralık: 100400), tedavi sonrası nötrofil sayısı: $2500 / \mathrm{mm}^{3}$ (aralık 930-7900)

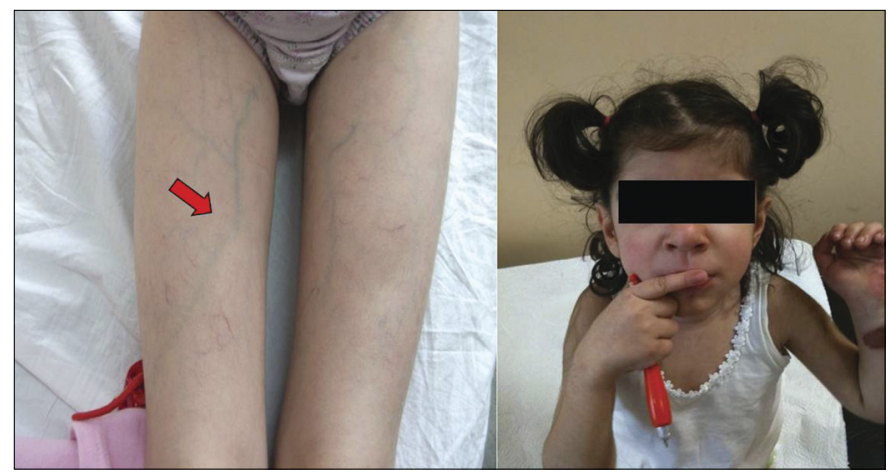

Şekil 1. Olgu 5'te G6PC3 mutasyonu ile uyumlu olabilecek yüzeyel deri venlerinde belirginleşme (kırmı ok), olgu 3'te nöromotor gelişme geriliği

Tablo 1. Doğuştan ağır nötropenide genetik bozukluklar

\begin{tabular}{|l|l|l|}
\hline Ağır nötropeni tipi & Etkilenen gen & Özellikler \\
\hline ELA2 eksikliği (OMIM: 202700) & ELA-2 & OB veya sporadik geçiş \\
\hline HAX1 eksikliği (OMIM: 610738) & HAX-1 & OÇ geçiş, nörolojik bulgular \\
\hline G6PC3 eksikliği (OMIM: 611045) & G6PC3 & OÇ geçiş, yüzeyel venlerde belirginleşme, kalp bulguları ve ürogenital anomaliler \\
\hline X' e bağlı nötropeni (OMIM: 300392) & WAS & X'e bağlı geçiş, T ve doğal öldürücü hücrelerde düşüklük eşlik edebilir \\
\hline GFI-1 eksikliği (OMIM: 600871) & GFI1 & OB geçiş, B ve T lenfositlere düşüklük eşlik edebilir \\
\hline
\end{tabular}

ELA2: Nötrofil elastaz, HAX1: HS1-ilişkili protein X-1, G6PC3: Glukoz 6 fosfataz katalitik subunit 3, WAS: Wiskott-Aldrich sendrom, GFI-1: Growth factor independent -1 


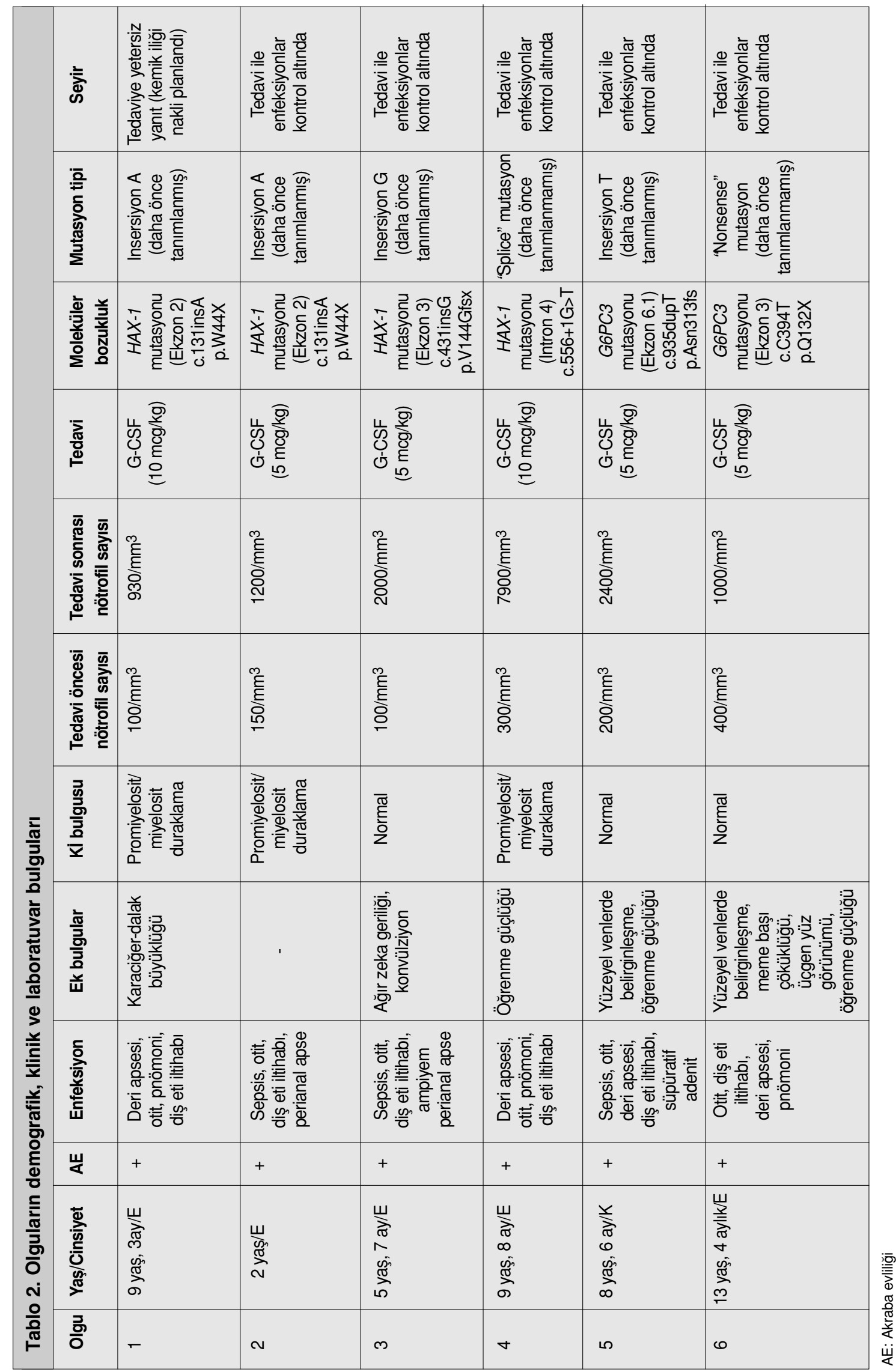


idi. Olgu beşte ek olarak lökopeni saptandı. Olguların hemoglobin ve trombosit sayılarında anormallik bulunmadı. İmmün yetersizlik açısından değerlendirilen immünoglobülin değerlerinin olgu 6 hariç (sınırda IgA eksikliği saptandı) normal veya yüksek olduğu görüldü. Lenfosit alt grubu incelemesinde ise olgu 6'da B lenfosit düşüklüğü dışında, diğerlerinin değerleri yaşa göre normal sınırlardaydı. Glükoz-6-fosfat katalitik alt birim 3 mutasyonu taşıyan olgu beşte HDL düşüklüğü (25 mg/dL), olgu altıda ise TSH yüksekliği görüldü. Olgu 5'in ekokardiyografik değerlendirmesinde mitral kapak yetersizliği saptandı. Geçirilmiş pnömoni ataklarına ikincil olabilecek akciğerde kronik değişiklikler (olgu 1,3,4), bronşektaziye ait bulgular (olgu 5 ve 6) görüldü.

\section{Mutasyon analizi}

Olguların dördünde $H A X 1$ geninde, ikisinde G6PC3 geninde mutasyon, esas gen ile karşılaştırılarak saptandı. Mutasyonların daha sonra tüm aile bireylerindeki taşıyıcılık oranları araştırıldı. Buna göre tüm olguların anne-babası taşıyıcı, kardeşlerin bir kısmı taşıyıcı iken diğerleri sağlıklıydı (Şekil 2). Bulunan mutasyonlar ve protein düzeyindeki etkileri aşağıdaki gibidir:

- Olgu 1: $H A X 1$, ekzon 2: DNA üzerinde nükleotid $A$ girişi (insersiyon $A$ ), protein düzeyinde durdurucu kodon oluşturarak protein sentezinin erken bitmesine neden olmakta, c.131insA p.W44X.

- Olgu 2: $H A X 1$, ekzon 2: DNA üzerinde nükleotid $A$ girişi (insersiyon $A$ ), protein düzeyinde durdurucu kodon oluşturarak protein sentezinin erken bitmesine neden olmakta, c.131insA p.W44X

- Olgu 3: HAX1, ekzon 3: DNA üzerinde nükleotid G girişi (insersiyon $\mathrm{G}$ ), protein düzeyinde çerçeve kayması oluşturarak protein sentezinin erken bitmesine neden olmakta, c.431insG p.V144Gfsx4.

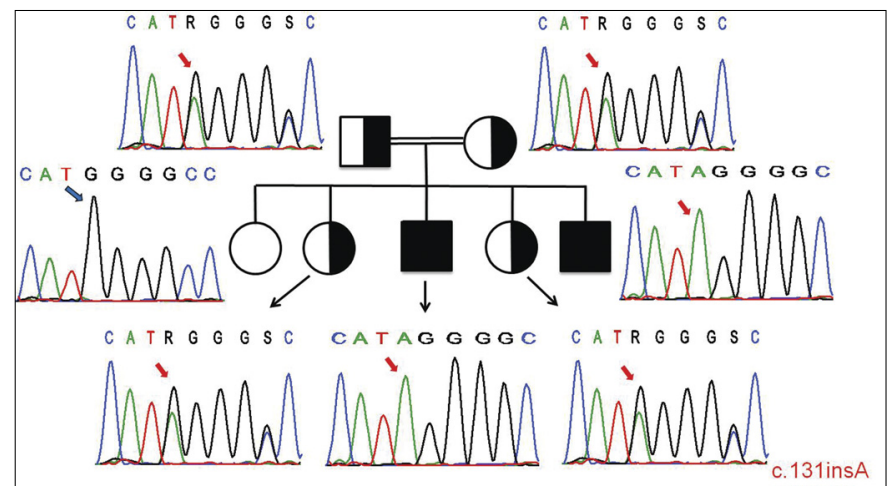

Şekil 2. Olgu 1 ve 2'nin tüm aile bireylerinde $H A X-1$ geni ekzon 2'de de mutasyon analizinin gösterilmesi. Deoksiribonükleik asit düzeyindeki gen diziliminin 131. bölgesine $A$ nükleotidi girişi ile TAG durdurucu kodon oluşumu, protein düzeyinde 44 . pozisyonunda W aminoasiti (Triptofan) yerine sentezin erken sonlanmasına neden olmaktadır (X). Anne-babanın ve iki kız kardeşin taşıyıcı (kırmızı ok), diğer kız kardeşin (mavi ok) sağlıklı olduğu görülmektedir. R: Belirsiz nükleotid (A veya $G$ ), W: Tiptofan, $X$ : protein sentezinin durduğunu ifade etmektedir
- Olgu 4: $H A X 1$, ekzon - intron 4 bağlantı noktası: DNA üzerinde nükleotid G'nin T'ye dönüşmesi, protein düzeyinde ilgili bölgenin kaybına neden olmakta, c.556+1G>T.

- Olgu 5: C6PC3, ekzon 6.1: DNA üzerinde nükleotid T girişi girişi (insersiyon $\mathrm{T}$ ), protein düzeyinde çerçeve kayması oluşturarak protein sentezinin anormal olmasına neden olmakta, c.935dupT - p.Asn313fs

- Olgu 6: $C 6 P C 3$, ekzon 3: DNA üzerinde nükleotid C'nin T'ye dönüşmesi ("nonsense"), protein düzeyinde durdurucu kodon oluşturarak protein sentezinin erken bitmesine neden olmakta, c.C394T - p.Q132X.

\section{Tedavi}

Tüm olgulara G-CSF tedavisi başlandı (5-10 mcg/kg). Tedavi altında mutlak nötrofil sayısı 1000/mm³ üzerinde iken enfeksiyon ataklarının azaldığı görüldü. Ortalama izlem süresi: 21,3 ay (aralık: 10-37 ay) olan olguların hiçbirinde miyelodisplastik sendrom veya akut miyeloid lösemi gelişmedi. Olgu birde uygun tedaviye rağmen yeterli yanıt alınmaması ve enfeksiyonların kontrol altına alınmaması nedeniyle kemik iliği nakli hazırlığına başlandı.

\section{Tartışma}

Doğuştan ağır nötropenide klinik çoğu zaman ilk altı ay içinde omfalit, apse oluşumu, otit, diş eti iltihabı ve pnömoni gibi ağır enfeksiyon tablosu ile bulgu verir. Diğer birincil immün yetersizliklerde daha fazla görülen sinüzit, pnömoni ve ishalden farklı olarak apse, ülser, diş eti iltihabı bulgularının varlığında nötrofil sayısının düşüklüğü bu tanıyı düşündürmelidir. Kemik iliği incelemesinde granülositer serinin erken evresinde gelişim duraklaması görülmekle beraber son yıllarda kemik iliğinde nötrofil gelişimi normal olan olgular da tanımlanmıştır (6). Kendi serimizin değerlendirilmesinde üç olguda normal nötrofil gelişimi gözlenmiştir.

Çalışmamızda incelenen olgularda bulguların genellikle yaşamın ilk altı ayı içinde çıktığı ve doktora başvurmasına rağmen tanıda belirgin derecede gecikme olduğu saptanmıştır (ortalama: 38,3 ay). Bu hastaların değerlendirilmesinde nötrofil sayısının gözardı edilerek sadece beyaz küre sayısına önem verilmesi tanıda gecikmelere ve buna bağlı olarak da hastalık ve ölümde artışa neden olmaktadır. Yine benzer şekilde, enfeksiyon ve nötropeni dışında bu olgularda konvülziyon, zeka geriliği gibi nörolojik bulgular saptanması ve bu bulguların nötropeniyle ilişkili olabileceğinin bilinmemesi tanıda gecikmeye neden olan ikinci etmendir.

Periferik yaymada nötropeninin yanı sıra monosit ve eozinofil sayısında artış saptanabilir. Tekrarlayan enfeksiyon atakları nedeniyle serum immünglobülin düzeylerinde artış görülebilir $(1,7)$. Ayrıca olguların \%40'ında osteopeni ve osteoporoz saptanabilir. Tanımladığımız altı olgunun üçünde tüm serum immünglobülin değerlerinde artış bulunmuştur. Diğer üç olgunun değerleri normal sınırlarda iken bir olguda hafif düzeyde IgA eksikliği saptanmıştır. 
Doğuştan ağır nötropenide hastalığı açıklayacak mutasyonlar tanımlanmaya başlanmış ve lokus heterojenitesine bağlı olarak farklı genlerdeki mutasyonların DAN'a neden olabileceği gözlenmiștir $(3,4)$. Şimdiye kadar sıklık sırasına göre DAN ile ilişkili olabilecek ELA2/ELANE, HAX-1, G6PC3, GFI1 ve WASP gen mutasyonları tanımlanmışıtı. Illk tanımlanan mutasyon nötrofil elastaz ile ilişkili olan ELA2/ELANE genindedir (8). Mutasyon sonucu endoplazmik retikulumda artan strese bağlı olarak hücre içinde biçimlenmemiş protein birikimlerinin oluştuğu ve bunun sonucunda erken gelişim evresinde nötrofillerin programlı hücre ölümüne yöneldiği gözlenmiştir (3). Bu mutasyon $\mathrm{OB}$ veya sporadik olarak kalıtımaktadır. Son yıllarda tanımlanmış olan diğer mutasyon ise HAX1 (HS1-ilişkili protein X-1) geninde olup 2007 yılında DAN ile ilişkisi bulunmuştur. Bu mutasyon aynı zamanda Kostman ve ark. (9) tarafından tanımlanan aile bireylerinde de daha sonradan saptanmıştır. HS1-ilişkili protein $\mathrm{X}-1$ proteini mitokondri içinde yerleşmiş olup sinyal iletiminde görev yapmaktadır. Eksikliğinde mitokondri duvarındaki potansiyelin bozulduğu programlı hücre ölümüne neden olmaktadır (3). HS1-ilişkili protein X-1 proteini hemopoeitik hücrelerin dişında fibroblast ve nöron hücrelerinde de sentezlenmekte, bu nedenle mutasyonu taşıyanların bir bölümünde değişik ağırlıkta nörolojik etkilenme meydana gelebilmektedir. Öğrenme güçlüğü, gelişme geriliği, konvülziyon ve nötropeni birlikteliğinde bu mutasyon akılda tutulmalıdır. Yapılan DNA dizileme çalışmalarında $H A X 1$ proteinin sadece bir izoformunu etkileyen mutasyonlarda nörolojik etkilenme görülmezken, her iki izoformu etkileyen mutasyon varlığında nörolojik tutulum oluşmaktadır $(2,9)$. Literatürde en çok tanımlanan mutasyon tipi olan ekzon 2'deki insersiyon A sonucu olan mutasyondur. Bu olguların çoğunun kökeni akraba evliliğinin sık olduğu ülkemizden tanımlanmış olup, en çok sepsis, otit, gingivit, deri apsesi, dalak büyüklüğü, büyüme gelişme geriliği gibi klinik bulgularla ortaya çıkmıştır. Görülen bulgular olgularımızda görülenler ile benzerlik göstermekteydi. Diğer taraftan, nörolojik bulgular ile ilişkili mutasyonlar İsveç, Türk ve Japon kökenli ailelerde tanımlanmış olup bunlarda epilepsi ve zeka geriliği görülmüştür. Bu gruptaki mutasyonlar protein sentezinin erken sonlanmasına neden olarak işlev bozukluğu yaratmaktadır (p.Val144fs, p.Gln123fs, p.Gln190X). Çalışmamızda, HAX1 mutasyonu taşıyan dört olgunun ikisi nörolojik olarak normal idi ve bu iki olguda görülen mutasyon daha önceden tanımlanmış olup HAX1 geninin sadece bir izoformunu etkilemekteydi (olgu 1 ve 2). Diğer iki olgumuzun birinde öğrenme güçlüğü (gözlenen mutasyon önceden tanımlanmamış olup, dördüncü ekzon-intron bağlantı bölgesinde saptandı-olgu 4), diğerinde ağır gelişim geriliği ve konvülziyon görülmüştür. Bu olguda daha önceden tanımlanmış olan mutasyon bulundu (olgu 3).

Son yıllarda DAN olgularında hastalı̆ga neden olabilecek OÇ kalııım gösteren G6PC3 (glükoz 6 fosfataz katalitik subunit 3) mutasyonu tanımlandı (10). Sendromik nötropeni olarak isimlendirilen bu grupta yüzeyel deri venlerinde belirginlik, kalp ve ürogenital anomaliler en sık görülen bulgulardır. Glükoz 6 fosfataz kompleksi içinde yer alan G6PC3 proteini endoplazmik retikulumda yerleşmiş olup sitoplazmadan endoplazmik retikulum içerisine glükoz 6 fostatın taşınmasında görev almaktadır $(3,6,10)$. Eksikliğinde nötrofillerde programlı hücre ölümü artmakta ve buna bağlı olarak ağır nötropeni meydana gelmektedir. Bu olgularda kemik iliğinde granülositer seride gelişim duraklaması beklenen bulgu olmasına rağmen, tanımlanmış bazı olgularda kemik iliğinde normal nötrofil gelişimi, hipoplazi, hiperplazi ve displastik değişiklikler de görülmüştür (6). Miyeloid hücrelerde vaküolizasyon görülen olgular da bulunmaktadır (11). Deri bulguları olarak en sık yüzeyel venlerde belirginleşme saptanırken, deri esnekliğinde artış, küçük ve içe dönük meme başları bazı olgularda görülmüştür. Kalp anomalileri arasında en sık atriyal septal defekt, patent duktus arteriyozus daha nadir olarak pulmoner kapak darlığı, pulmoner hipertansiyon, hipoplastik sol kalp sendromu ve biküspit aorta görülmesinin yanında ürogenital anomali olarak böbrek agenezi, hidronefroz, urakal fistül, ambigus genitaliya, inmemiş testis, mikropenis, inguinal fitık tanımlanmışıı (6,11-13). Bu olguların bir bölümünde frontal çıkıklık, üçgen yüz görünümü, malar düzleşme, işitme kaybı, öğrenme güçlüğü, skolyoz ve pektus karinatus görülebilmektedir. Literatürde tanımlanan Dursun sendromu (13) olan olgularda G6PC3 mutasyonu gösterilmiştir. $\mathrm{Bu}$ olgularda nötropeniye eşlik eden pulmoner hipertansiyon bulunmaktadır. Dursun sendromu G6PC3 mutasyonuna bağlı gelişen DAN'nin bir alt tipi olarak değerlendirilmektedir (13). Laboratuvar olarak nötropenin dışında trombositopeni, TSH ve ürik asit yüksekliği, HDL düşüklüğü, büyüme hormonu eksikliği bazı olgularda gözlenmiştir (6). Bu hastalarda miyelodisplastik sendrom ve akut miyeloid lösemi gelişim riskinin diğer DAN tiplerine göre daha düşük olabileceği vurgulanmıştır (14). Bugüne kadar tanımlanan 31 olgunun çoğu Ortadoğu kökenli (Türkiye, İran, Lübnan) ailelerde görülmüştür. Mutasyonların çoğu ekzon altıda saptanmış olup, en sık görüleni c,758G >A yanlış anlamlı mutasyonu ve protein düzeyinde aminoasit değişimidir (p,Arg253His). Bunun yanı sıra, G6PC3 mutasyonları ile farklı klinik bulgular arasında genotip-fenotip ilişkisi kurulamamıştır $(14,15)$. Kendi serimizdeki iki olguda yüzeyel venlerde belirginleşme, öğrenme güçlüğü, olgu 5'te HDL düşüklüğü, olgu 6 'da üçgen yüz görünümü ve mitral kapak yetersizliği saptanmış ancak ürogenital anomali görülmemiştir. Olgu 6'daki mutasyon daha önce tanımlanmamış olup, nükleotit değişimi sonucu "dur" kodonu oluşturarak kısa protein üretimine neden olduğu görülmüştür (p.Q132X).

Klinik değerlendirme sırasında nötropeni olgularında fenotipik özelliklerin varlı̆̆ı, olası mutasyonların değerlendirilmesi açısından önemlidir. Örneğin nörolojik problemler HAX1 mutasyonu, deride yüzeyel venlerin varlığı, kalp ve ürogenital anomaliler G6PC3 mutasyonunu düşündürmelidir. Kalıtsal hastalıkların tekrarlama riskleri nedeniyle bu olgulara genetik danışma verilmesi ve mutasyon tayini sonrası doğacak çocuklara doğum öncesi genetik tanı sağlanması önemlidir.

Ağır doğuştan nötropeniye neden olabilecek daha nadir genler WAS ve GFI-1'dir (16). Wiskott-Aldrich sendromu 
genindeki mutasyon X'e bağlı nötropeniye neden olmakta ve bu mutasyonda klasik WAS'da görülen egzema, trompositopeni gibi bulgular görülmemektedir. "Growth factor independent"-1 proteini granülositlerin gelişiminde ve farklılaşmasında büyüme faktörü olarak görev yapmaktadır. Bu mutasyon varlığında nötropeniye T hücre düşüklüğü eşlik edebilmektedir (17).

Hastalığın tedavisinde amaçlanan en önemli hedef enfeksiyon sıklığının ve hastaneye yatışların azaltılmasıdır. Tercih edilecek tedavidir. Tedavi ile nötrofillerin gelişimi, farklılaşması hızlanmakta, hücre ölümü azalmakta ve böylece olgunlaşmış nötrofil sayısı artmaktadır. Kullanılan doz 3-5 $\mu \mathrm{g} / \mathrm{kg}$ deri altı uygulama şeklindedir $(2,4)$. Ancak tedaviye verilen yanıt değişkenlik gösterir ve bazı olgularda 1000/mm³ üzerinde nötrofil sayısı elde etmek için daha yüksek dozlar kullanmak gerekebilmektedir. İzlem sırasında \%20 olguda miyelodisplastik sendrom veya akut miyeloid lösemi gelişim riski olduğundan yıllık kemik iliği incelemesi ve G-CSF almaç gen mutasyon analizi yapılması önerilmektedir (18). Lösemi gelişen olguların \%80'ninde granülosit koloni uyarıcı faktör almaç mutasyonu gözlendiği için malinite gelişiminde bu mutasyonun rolü olduğu düşünülmektedir. Tedaviye yanıtsızlık ve izlem sırasında miyelodisplastik sendrom veya akut miyeloid lösemi gelişen olgularda kemik iliği nakli yapılmalıdır (3). Bu hastalarda görülen enfeksiyonlar, hematolojik değişiklikler ve nörolojik bulgular nedeniyle çok merkezli olarak immünoloji, hematoloji ve nöroloji dalları tarafından ortak izlenmesinde fayda vardır.

Sonuç olarak, DAN nadir görülen ancak ağır enfeksiyonlar nedeniyle erken dönemde ölüme neden olan bir hastalık grubudur. Tekrarlayıcı ağır enfeksiyonların yanı sıra zeka geriliği, yüzeyel deri venlerinde belirginlik, kalp ve ürogenital anomali öyküsü olan olgularda nötrofil sayısına dikkat edilmesi gerekir. Kalıtımsal geçiş nedeniyle mutasyon analizi ve genetik danışmanın yapılması erken teşhis ve tedavi açısından önemlidir.

\section{Çıkar çatışması: Bildirilmemiştir.}

\section{Kaynaklar}

1. Welte K, Zeidler C, Dale DC. Severe congenital neutropenia. Semin Hematol 2006; 43(3): 189-95.

2. Kostmann R. Infantile genetic agranulocytosis: a new recessive lethal disease in man. Acta Paediatr Scand 1956; 45: 1-78.

3. Boztug K, Klein C. Genetic etiologies of severe congenital neutropenia. Curr Opin Pediatr 2011; 23(1): 21-6.

4. Boztug K, Klein C. Novel genetic etiologies of severe congenital neutropenia. Curr Opin Immunol 2009; 21: 472-80.

5. Kılıçbay F, Kılıç SŞ. Siklik nötropeni ve konjenital nötropeni (Kostmann hastalığı). Güncel Pediatri 2004; 2: 64-8.

6. Banka S, Chervinsky E, Newman WG, et al. Further delineation of the phenotype of severe congenital neutropenia type 4 due to mutations in G6PC3. Eur J Hum Genet 2011; 19: 18-22.

7. Rezaei N, Moin M, Pourpak Z, et al. The clinical, immunohematological, and molecular study of Iranian patients with severe congenital neutropenia. J Clin Immunol 2007; 27: 525-33.

8. Dale DC, Person RE, Bolyard AA, et al. Mutations in the gene encoding neutrophil elastase in congenital and cyclic neutropenia. Blood 2000; 96: 2317-22.

9. Klein C, GrudzienM, Appaswamy G, et al. HAX1 deficiency causes autosomal recessive severe congenital neutropenia (Kostmann disease). Nat Genet 2007; 39: 86-92.

10. Boztug K, Appaswamy G, Ashikov A, et al. A syndrome with congenital neutropenia and mutations in G6PC3. N Engl J Med 2009; 360: 32-43.

11. Banka S, Newman WG, Ozgül RK, Dursun A. Mutations in the G6PC3 gene cause Dursun syndrome. Am J Med Genet A 2010; 152A: 2609-11.

12. Arostegui JI, de Toledo JS, Pascal M, Garcia C, Yague J, Diaz de Heredia C. A novel G6PC3 homozygous 1-bp deletion as a cause of severe congenital neutropenia. Blood 2009; 114: 1718-9.

13. Dursun A, Ozgul RK, Soydas A, et al. Familial pulmonary arterial hypertension, leucopenia, and atrial septal defect: a probable new familial syndrome with multisystem involvement. Clin Dysmorphol 2009; 18: 19-23.

14. Boztug K, Rosenberg PS, Dorda M, et al. Extended spectrum of human glucose-6-phosphatase catalytic subunit 3 deficiency: novel genotypes and phenotypic variability in severe congenital neutropenia. J Pediatr 2011; 160: 679-83.

15. Banka S, Wynn R, Newman WG. Variability of bone marrow morphology in G6PC3 mutations: is there a genotype-phenotype correlation or agedependent relationship?. Am J Hematol 2011; 86: 235-7.

16. Klein $\mathrm{C}$. Genetic defects in severe congenital neutropenia: emerging insights into life and death of human neutrophil granulocytes. Annu Rev Immunol 2011; 29: 399-413.

17. Rezaei N, Moazzami K, Aghamohammadi A, Klein C. Neutropenia and primary immunodeficiency diseases. Int Rev Immunol 2009; 28: 335-66.

18. Klein C. Congenital neutropenia. Hematology Am Soc Hematol Educ Program 2009: 344-50. 